Meta

Journal des traducteurs

Translators' Journal

\title{
Interpretation, Translation and Communication in Canada's
} Far North

\section{Louise Nicklen}

Volume 28, numéro 2, juin 1983

URI : https://id.erudit.org/iderudit/003732ar

DOI : https://doi.org/10.7202/003732ar

Aller au sommaire du numéro

Éditeur(s)

Les Presses de l'Université de Montréal

ISSN

0026-0452 (imprimé)

1492-1421 (numérique)

Découvrir la revue

Citer cet article

Nicklen, L. (1983). Interpretation, Translation and Communication in Canada's Far North. Meta, 28(2), 153-156. https://doi.org/10.7202/003732ar d'utilisation que vous pouvez consulter en ligne.

https://apropos.erudit.org/fr/usagers/politique-dutilisation/ 


\title{
INTERPRETATION, TRANSLATION AND COMMUNICATION IN CANADA'S FAR NORTH
}

\author{
LOUISE NiCKLEN
}

The Northwest Territories (NWT) is a geographical and political region that stretches 1,2 million square miles across the top of Canada and its 48000 residents are scattered amongst some 50 communities located on what many southerners describe as a lunar landscape at the best of times.

The Legislative Assembly of the Northwest Territories represents these northern inhabitants and the majority of its members speak only the aboriginal languages well. It is against this setting that the Language Bureau - a professionally trained group of interpreter/translators - was formed within the government's Department of Information.

According to Deputy Minister Art Sorensen: "The bureau is unique. I'm not aware of any other jurisdiction that has tackled the language problem on such a diverse scale. It's like an organized Tower of Babel.'

Members of the bureau provide language services for two distinct aboriginal cultures - Inuit who speak Inuktitut (Eskimo) and Dene (Indian) languages ${ }^{1}$. There are two main Inuktitut languages and five Dene or Athapaskan languages. In addition, both language groupings have numerous local dialects.

"And," says Sorensen, "if that isn't enough, there is a rather traumatic lack of word equivalents between the English and Native languages, which are generally a lot more down-to-earth in their application."

In Inuktitut the word uqsualuk ('big piece of fat') is used to translate the English word oil. In English, you would say sugar; in Inuktitut you say siuraujaaqtuq ('what feels and looks like sand') ${ }^{2}$.

Over the years, members of the Bureau have compiled word lists to assist them in their day-to-day interpreting assignments. On a regular basis they come together as a group to work with linguists in a further attempt to cope with the never-ending flood of bureaucratic buzzwords that can, on occasion, befuddle the best of us.

The Language Bureau is staffed by 13 Inuit interpreter/translators and 8 Dene interpreter/communicators. The difference is that the Inuit interpreter

1. Inuit is the Eskimo's own name for themselves, and they prefer to be known by it. It is the plural or collective forms; the singular is Inuk. Inuktitut is the language. Dene means 'nation'.

2. Curiously enough, the English word sugar is remotely related to the Sanskrit word for 'sand'. 
corps has existed for some time, whereas the Dene employees are new to the bureau and are involved in a costly and comprehensive training program in interpreting and language skills as well as the skills required to undertake the task of public affairs officer for the department.

The purpose of all these professional people is to assist native residents of the NWT, particularly those who speak only one language, to communicate with a government that for the most part speaks English only, and to help them gain information in their respective languages on the complex issues being debated and decided in the Canadian North today.

Those issues range from cost of living indexes, through education, wildlife and social assistance to constitutional development, land claims, petrochemical developments and atomic energy.

This means that members of the bureau must bring a variety of skills to their jobs : simultaneous interpreting for the 22-member Legislative Assembly, translation of government documents into written native languages, interpreting services at community meetings. The interpreter/communicators are even required to perform a kind of social work at times, as native people who cannot speak English are naturally drawn to the interpreters to help them find their way through such governement jargon as, for example, "to mitigate the effects of non-renewable resource development on the harvesting of renewable resources."

By far their most difficult task is the preservation and renewal of their own language, particularly amongst the Dene people. Because of their speakers' long association with Europeans in the western NWT, some of the Dene languages have been, until recently, dying or - for that matter - on the deathbed.

Amongst the Loucheux, there are presently only about 265 people left in the NWT who speak the language and only three or four who write it - a sobering thought to members of the Bureau committed to the preservation of a language and, inevitably, the culture that goes with it.

Dene members of the Bureau spend many hours in the classroom learning to read and write their own language as well as in upgrading their level of English language comprehension. A language commission recently voted to adopt romanized orthography over the older syllabic form of writing, but progress is slow as instructors for the new orthography are scarce and in high demand.

The same is not the case with Inuit members of the Bureau.

Their syllabic writing system is well established and is being used on a daily basis. Computer systems have been developed by the Bureau to do word processing syllabics and to print in the same script at 500 words per minute using a letter-quality daisy wheel printer. In addition, translated material is being transmitted to regional offices located throughout the NWT via telephone modem and investigations are underway to into the practicality of a computerassisted translation program modelled after a system that has been developed in the United States for other languages. 
Dene members of the bureau will use an audio-visual approach as one method of assisting government to communicate in native languages, until the written form of their tongue is more fully developped and widely used.

Thus video-tapes will be produced and distributed and played back over facilities the department expects to install in Dene communities throughout the western Arctic. The tapes will at first be three-quarter inch format, but Department is already planning to introduce a half-inch Betamax format for use on a growing number of domestic video playback machines in NWT households.

These exciting developments and innovations in the Language Bureau will allow the NWT's 13000 Inuktitut speakers and 5000 Dene language speakers to participate more fully in the government's affairs and the long-range political and economic evolution of Canada's North. In this our interpreter/translators and interpreter/communicators have a key role to play.

\section{APPENDIX}

\section{English Text}

The English speaking member of the Northwest Territories Legislative Assembly could have been excused for wondering why his colleagues and a small group of people in the public gallery were laughing so much at what he considered a pretty feeble attempt at humour.

He knew that what he had said wasn't really all that funny. He also knew that the Inuit (Eskimo) members of the House were laughing the most.

Speculating that something had been lost or added in the simultaneous interpretation of his remarks, he crossed the floor to sit with a member of the Northwest Territories Language Bureau. The interpreter couldn't bring herself to tell him. Later she confided that she had instructed his colleagues to "laugh very hard. The honorable member has just told a very funny joke and I don't know how to interpret it."

\section{Inuktitut Translation (Syllabic Script)}

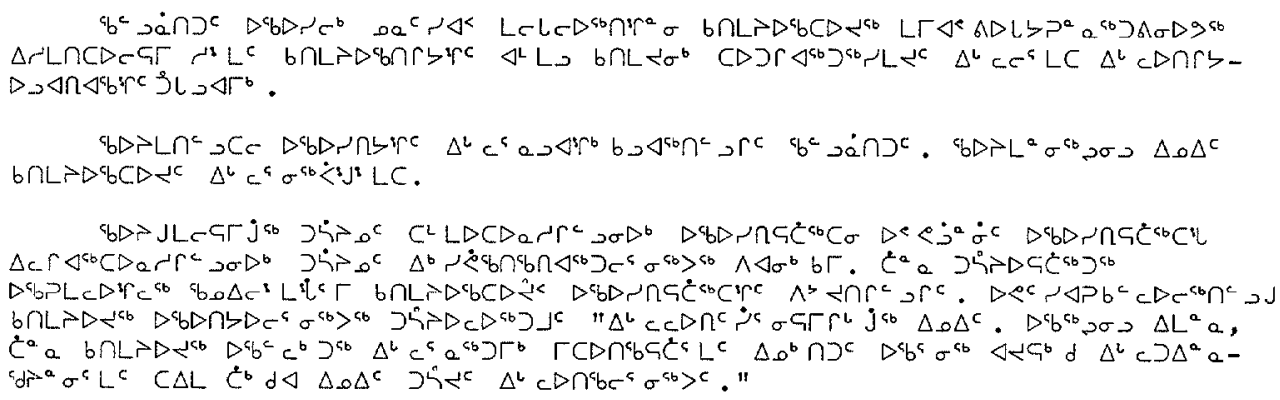


156

META, XXVIII, 2

Slavey (Dene) Translation (Romanized Orthography) N.B. Typewriters are not yet available for this language.

Dene Kie beqha Telekéte Tets'e déwe ke Gohkudé qha kiedéwe Teqúyeni dene léqi móla kie denetá qohde, hayile bélek, e kidtodade, dtógohwq jadeyidile Gots'e dákiedi hie rakiedl yeniwl

Erák,e kie leyidéhwl hęteyá gots'élóne rálekiédxo Gónezé sexedé Kie qots'é yidéle hüredi yeniwi, haqu lahtaleti dahódekie Kolú tasisayedeycdile. Kiola yenóta Gúni lekiá ladi Kiryédi, leyi dene goicha dtógohwe lade yldl kidu beketá redédele Gha duye hie Gëcha ráradto kió deyidi hie yá laksedeyı́di, hadi kĭyéd. 